\title{
INDUSTRY STANDARD OF THE LAND MANAGEMENT PROJECT ON \\ THE ORGANIZATION OF THE TERRITORY OF STATE SCIENTIFIC INSTITUTIONS
}

Dorosh Y., Doctor of economics

E-mail: landukrainenaas@gmail.com

Kharytonenko R., Candidate of Economic Sciences

E-mail: kharytonenkor@gmail.com

Institute of Land Management

of the National Academy of Agrarian Sciences of Ukraine

Butenko E., Candidate of Economic Sciences

E-mail:evg_cat@ukr.net

National University of Life and Environmental Sciences of Ukraine

Melnyk D., Candidate of Economic Sciences

E-mail: melnykdenys@gmail.com

Institute of Land Management

of the National Academy of Agrarian Sciences of Ukraine

The normative legal acts, scientific publications and land management projects on the organization of the territory in particular of the state scientific institutions and enterprises of the National Academy of Agrarian Sciences of Ukraine (hereinafter - NAAS) are analyzed. It is established that in the current legislation there is no type of land management documentation to address the organization of land use of state institutions and enterprises of NAAS. Emphasis is placed on the need to develop an industry standard that will take into account the specifics of land use of NAAS institutions and enterprises, which include land, research fields, nurseries, valuable land for research, which must be taken into account when developing land management documentation. The definition of the term organization of the territory is offered. The design of regulatory documents (industry standard) in accordance with State Standard of Ukraine 1.5: 2015, which indicates the typical structural elements that need to be shown when developing the 
standard. The branch standard of the land management project concerning the organization of the territory of land use of the state establishments and the enterprises of NAAS is offered taking into account specific functional features of use of the agricultural lands of the state establishments and the enterprises of NAAS.

Key words: standardization, industry standard, organization of territory, research land use, NAAS.

Formulation of the problem. One of the necessary conditions for sustainable development of land use and effective spatial planning is the harmonization of the system of national norms and rules. This was no exception in the development of land management documentation.

In accordance with Article 23 of the Law of Ukraine "On Land Management" regulations on land management establish the organization, state standards, norms and rules of land management, their composition and content [1]. In this regard, in order to increase productivity and ensure the stability of land use, the development of land management documentation for agricultural enterprises is important because it provides measures for efficient land use and implementation of scientific systems of agriculture, scientific and technological progress and environmental requirements.

State institutions and enterprises are a branch of a set of scientific and production units, enterprises and organizations that carry out the same or similar types of scientific and industrial activities, characterized by a common feature of scientific and industrial activities. In the absence of a state standard or in the case of the need to establish requirements that exceed or supplement the requirements of the state standard, an industry standard is developed. Currently, there are only scattered sets of information on the organization of land use. Also, the existing information does not fully take into account the specific features of land use of government agencies and enterprises engaged in research activities in agriculture [2].

Analysis of recent research and publications. Creation of a single state system of standards, norms and rules in the field of land management, use and protection of land is provided by the norms of current land legislation. However, for a long time 
this issue was not given much attention by scientists. Some developments in this direction began to appear during the research work of the profile institution of the land management industry of the Institute of Land Use of NAAS of Ukraine.

In particular, Dorosh Y. and Avramchuk B. investigated the issues of scientific approaches to the development of an industry standard for the organization of the territory of institutions engaged in agricultural research and educational activities. For the first time they raised the issue of the need to develop the composition, content of the industry standard of organization of the territory [3].

DoroshY., Dorosh O., Kharytonenko R., Melnyk D. investigated the need to develop an industry standard on the example of land inventory of government agencies and enterprises of NAAS. They also proposed the structure, content and composition of the main provisions of this industry standard, which takes into account the "specific" features in the use of land institutions and enterprises of NAAS [2].

In view of this, further research should be aimed at improving scientific approaches to the organization of the territory of agricultural state research institutions and the development of an industry standard that will be a tool for land management.

The aim of the study. To specify the formed scientific approaches to the organization of the territory of research institutions and to offer the branch standard of the project of the land management concerning the organization of the territory of land uses of the state scientific institutions (on an example of NAAS).

Results of research and discussion. The organization of production in agricultural enterprises is to some extent related to land use. The land massifs themselves, their boundaries, taking into account internal production units; territorial features of land use and resettlement system determine the organizational and production structure of the enterprise. However, an effective system of management and organization of production of an agricultural enterprise is impossible without a rational organization of the territory. In regulations there is no concept of the term organization of the territory. In accordance with the urban planning legislation of 
Article 1 definition of the Law of Ukraine "On regulation of urban planning" under the term "territory" defined part of the earth's surface with airspace and subsoil located below it within certain limits (borders), which has a certain geographical position the result of human activity conditions and resources [4].

The term organization should be understood as a tool, mainly interpreted as a designation of a social group that distributes the tasks among the participants to achieve a certain collective goal. In this context, the organization of the territory is to achieve efficient use of land resources within a particular agricultural enterprise and achieve economic growth. It should also be noted that the organization of the territory is present in Article 181 of the concept of land management of the Land Code of Ukraine. In this case, the organization of rational use and protection of land and the territorial organization of production are considered to be the two main tasks of land management [5].

Thus, the term organization of the territory can be interpreted as a tool, arranging a specific part of the earth's surface together with other objects and means of production, inextricably linked to the land, bringing them into a certain system, establishing order on the ground corresponding to specific production economic, technological, environmental and social goals.

In order to have a systematic and planned approach to improving the regulatory framework, it is necessary to determine the main provisions of the industry standard of such a land management project. When developing the industry standard of the land management project on the organization of the territory of state scientific institutions and enterprises of NAAS in order to create spatial conditions for ecological and economic optimization of use and protection of agricultural lands it is necessary to take into account soil and climatic potential. Also, in accordance with the task of developing a land management project, the project documentation should consist of text and graphic parts. The text part will include a technical task, an explanatory note and appendices.

The technical task consists of: the bases for performance of works on the organization of the territory of the state scientific institutions or the enterprises of 
NAAS; initial data provided by the customer (materials of previously developed land management documentation); materials submitted based on the results of the works (prescribed individually with the customer of the works, prescribed in the list of materials issued to the customer for the organization of the territory as a result of its implementation) [3].

Given the work of Dorosh Y. and Avramchuk B. in the work "Scientific approaches to the development of industry standards for the organization of the territory of institutions engaged in agricultural research and educational activities" we propose to supplement the explanatory note with a section - the formation of an electronic document [3]. Thus, the explanatory note will consist of seven sections, which regulate the main points in the conduct of land management work on the organization of the territory during project development, in particular: 1. General provisions; 2. Geodetic surveys; 3. Land management design (organization of lands of scientific institutions); 4. Approval and approval of the project; 5 . Transfer of the project in kind (on the ground); 6. Formation of an electronic document; 7. The order of storage of land management documentation.

Appendices, as an integral part of the text, should include the following materials, which include: Initial data for the development of a land management project; 1. Materials of geodetic surveys and land management design; 2. Lists of land plots (lands) of state institutions and enterprises of NAAS by categories of lands and lands provided for ownership (use), not provided for ownership or use, as well as those used without documents; 3. List of land plots (lands) of state institutions and enterprises of NAAS according to their functional use: zone of research fields; area for growing elite seeds and planting material of agricultural crops; regulated use area; zone of preservation of agro-soil, nature protection and historical-cultural complexes and objects valuable for agrarian science; economic zone; mode-forming objects; real estate and rights to it. 4. Lists of restrictions on the use of land plots (lands) of state institutions and enterprises of NAAS; 5. Materials for transferring the boundaries of land plots in kind (on the ground); 6. Materials for approval of the land management project; 7. Additional materials. 
Graphic materials of the land management project on the organization of the territory of state scientific institutions and enterprises of NAAS should include the following planning and cartographic materials: 1. Plan of the current state of land use; 2. Plan of agro-industrial groups of soils with terrain relief; 3. Scheme of agrotechnological groups of soils; 4. Plan of organization of the territory; 5. Plan for transfer to nature.

Taking into account the above conditions when developing a land management project for the organization of the territory of state scientific institutions and enterprises of NAAS, the structure of the content of the industry standard is proposed, which will be the basis for land management works for the development of this standard (Table 1).

In accordance with the rules of development, teaching and design of national regulations DSTU 1.5:2015 standard structural elements of the standard and the scheme of division of structural elements of the standard by level of subordination is divided into two structural elements: front structural elements; structural elements of the main part [6].

In the front structure of the element of the standard is placed: the title page; preface; content; introduction. In the structural element of the main part place: name; scope of application; normative references; terms and definitions; marks and abbreviations; requirements / provisions for the object of standardization; applications (required); applications (additional); bibliography; bibliographic data; Keywords.

In the front structure of the element and in the structural element of the main part in addition to the listed elements must be in the standard: title page, preface, table of contents, introduction, title, scope, requirements / provisions for the object of standardization, bibliography.

Conclusions. Today, the world and its trends are evolving very rapidly. The established rules, which were effective 10-15 years ago, today need to be comprehensively updated and clarified. Land legislation and land management in general are no exception, which requires the development of new norms, rules and 
restrictions. This approach is based on the standardization and unification of types of land management documentation, which will take into account the specifics of land use in accordance with their main purpose. In developing the industry standard of the land management project for the organization of the territory of state scientific institutions and enterprises of NAAS, the specifics of land use activities were taken into account, the lands of which are intended for agricultural research and educational activities. In this regard, the structure, content and composition of the main provisions, which will be the main tool in the development of land management documentation for the organization of land for agricultural research and educational activities used by these government agencies and enterprises of NAAS.

Thus, the proposed industry standard of the land management project for the organization of the territory of state scientific institutions and enterprises of the National Academy of Agrarian Sciences of Ukraine is an important step that should become a tool for effective land use of NAAS. 


\section{Structure, content and composition of the land management project on the organization of the territory}

\section{state scientific institutions and enterprises of NAAS}

\begin{tabular}{|c|c|c|}
\hline Structure & Content & Storage \\
\hline \multirow{19}{*}{ Text } & \multirow{4}{*}{$\begin{array}{l}\text { Terms of } \\
\text { reference }\end{array}$} & The basis for the organization of the territory \\
\hline & & Initial data provided by the customer (description) \\
\hline & & Materials submitted based on the results of the work \\
\hline & & $\begin{array}{l}\text { The list of materials issued to the customer of works on the organization of the territory by results of its } \\
\text { carrying out }\end{array}$ \\
\hline & \multirow{7}{*}{$\begin{array}{l}\text { Explanatory } \\
\text { note }\end{array}$} & Terms \\
\hline & & Geodetic surveys \\
\hline & & Land management design (organization of lands of scientific institutions) \\
\hline & & Project approval and approval \\
\hline & & Transfer of the project in kind (on the ground) \\
\hline & & Formation of an electronic document \\
\hline & & The order of storage of land management documentation \\
\hline & \multirow{8}{*}{ Additions } & Initial data for the development of a land management project \\
\hline & & Materials of geodetic surveys and land management design \\
\hline & & $\begin{array}{l}\text { Lists of land plots (lands) of state institutions and enterprises of NAAS by categories of lands and lands } \\
\text { provided for ownership (use), not provided for ownership or use, as well as those used without documents }\end{array}$ \\
\hline & & $\begin{array}{l}\text { List of land plots (lands) of state institutions and enterprises of NAAS according to their functional use: area } \\
\text { of research fields; area for growing elite seeds and planting material of agricultural crops; regulated use } \\
\text { area; zone of preservation of agro-soil, nature protection and historical-cultural complexes and objects } \\
\text { valuable for agrarian science; economic zone; mode-forming objects; real estate and rights to it. }\end{array}$ \\
\hline & & Lists of restrictions on the use of land plots (lands) of state institutions and enterprises of NAAS \\
\hline & & Materials for transferring the boundaries of land plots in kind (on the ground) \\
\hline & & Materials for approval of the land management project \\
\hline & & Additional materials \\
\hline \multirow{5}{*}{ Graphically } & & Plan of the current state of land use \\
\hline & & Plan of agro-industrial groups of soils with terrain \\
\hline & & Scheme of agro-technological groups of soils \\
\hline & & Territorial organization plan \\
\hline & & Transfer plan in kind \\
\hline
\end{tabular}




\section{The structure of the element of the industry standard of the land management project on the organization of the}

\section{territory state scientific institutions}

\begin{tabular}{|c|c|c|}
\hline Structural elements & $\begin{array}{l}\text { The name of the } \\
\text { structural element }\end{array}$ & The content of the structural element \\
\hline \multirow[t]{3}{*}{$\begin{array}{l}\text { Front structural } \\
\text { elements }\end{array}$} & Title page & 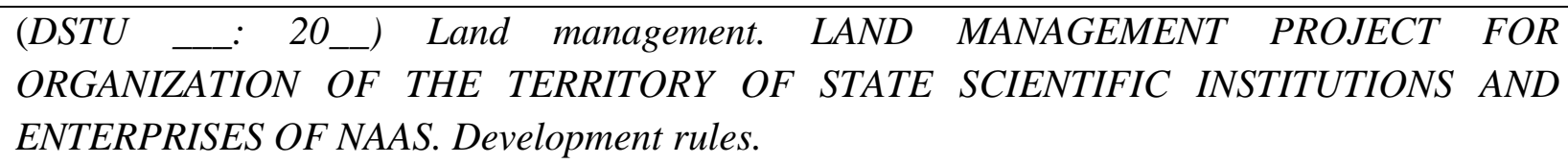 \\
\hline & Preface & $\begin{array}{l}\text { 1. DEVELOPED: Institute of Land Use of the National Academy of Agrarian Sciences of } \\
\text { Ukraine. } \\
\text { 2. ACCEPTED AND EFFECTIVE № } 20 \text {; } \\
\text { 3. This standard is developed according to the rules established in the national standardization } \\
\text { of Ukraine. } \\
\text { 4. INTRODUCED FOR THE FIRST TIME. }\end{array}$ \\
\hline & Content & $\begin{array}{l}\text { Introduction, Scope, Normative references, Terms and definitions, Requirements / provisions for } \\
\text { the object of standardization, Bibliographic data. }\end{array}$ \\
\hline \multirow[t]{3}{*}{$\begin{array}{l}\text { Structural elements of } \\
\text { the main part }\end{array}$} & Name & $\begin{array}{l}\text { Land management project for the organization of the territory of state scientific institutions and } \\
\text { enterprises of NAAS }\end{array}$ \\
\hline & Scope & $\begin{array}{l}\text { This industry standard establishes a set of measures related to the organization of the territory of } \\
\text { state scientific institutions and enterprises of NAAS, in particular scientific institutions whose } \\
\text { lands are provided for agricultural research and educational activities. }\end{array}$ \\
\hline & Regulatory references & \begin{tabular}{l} 
Land Code of Ukraine, \\
Law of Ukraine "On Land Management"; Law of Ukraine "On the State Land Cadastre"; \\
Law of Ukraine "On Scientific and Scientific-Technical Activity"; Resolution of the Cabinet of \\
Ministers of Ukraine of July 28, 2003 № 1180 "On approval of the list of paid services that may \\
be provided by budgetary scientific institutions". \\
DSTU 1.5: 2015 National standardization of the rules of construction, teaching, design and \\
requirements for the content of regulatory documents; \} $\\
{\text { Law of Ukraine "On topographic, geodetic and cartographic activities". Edition 07.06.2020 № }}$ \\
\hline
\end{tabular}
\end{tabular}




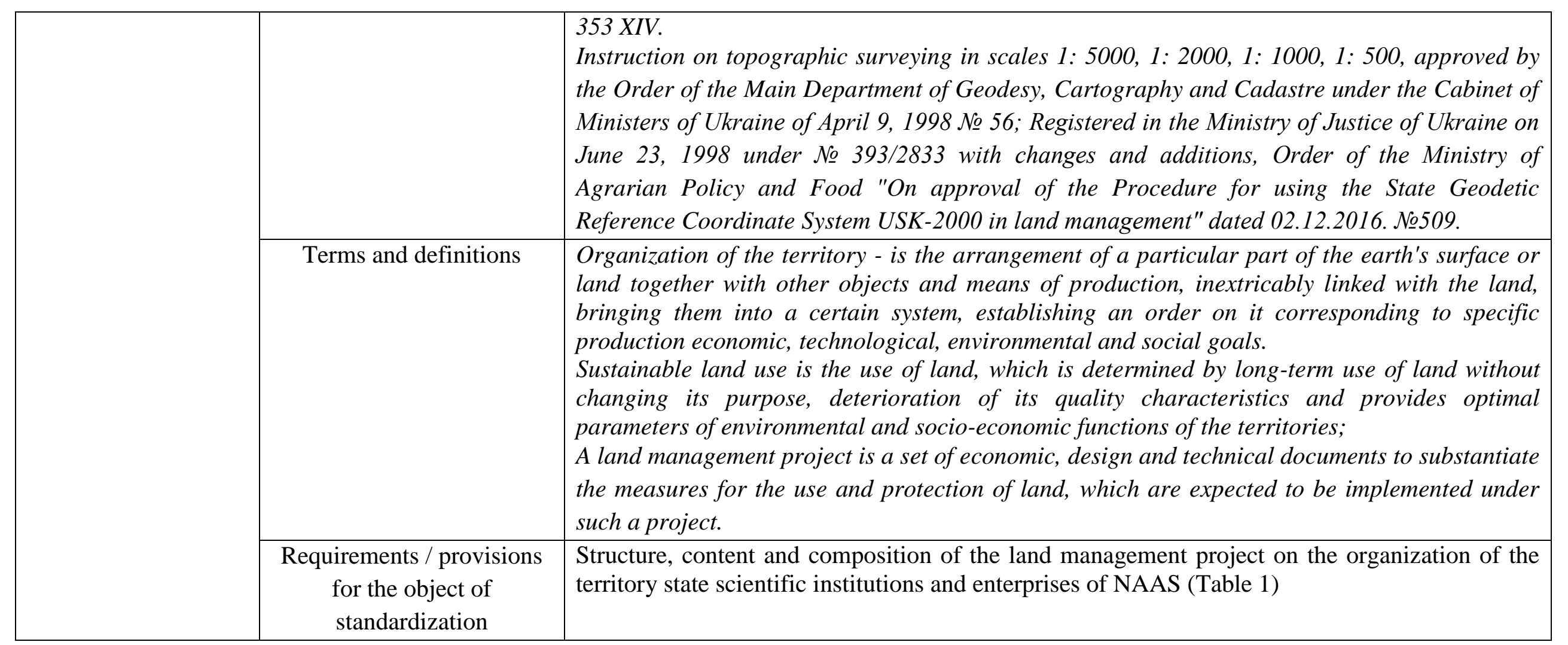




\section{References}

1. Zakon Ukrainy «Pro zemleustrii» vid 22.05.2003 roku № 858-IV. URL : http://zakon.rada.gov.ua/laws/show/858-15

2. Dorosh Y. M., Dorosh O. S., Kharytonenko R. A., Melnyk D. M. (2019) Propozytsii shchodo struktury, zmistu ta skladu haluzevoho standartu inventaryzatsii zemel derzhavnykh ustanov ta pidpryiemstv NAAN. Zemleustrii, kadastr i monitorynh zemel, 3, 15-22. doi: http://dx.doi.org/10.31548/zemleustriy2019.03.02

3. Dorosh Y. M., Avramchuk B. O. (2020). Naukovi pidkhody do rozrobky haluzevoho standartu proektu zemleustroiu shchodo orhanizatsii terytorii naukovykh ustanov, zemli yakykh nadani dlia zdiisnennia silskohospodarskoi naukovo-doslidnoi ta navchalnoi diialnosti. Zemleustrii, kadastr i monitorynh zemel, 1, 4-13. doi: http://dx.doi.org/10.31548/zemleustriy2020.01.01

4. Zakon Ukrainy «Pro rehuliuvannia mistobudivnoi diialnosti».

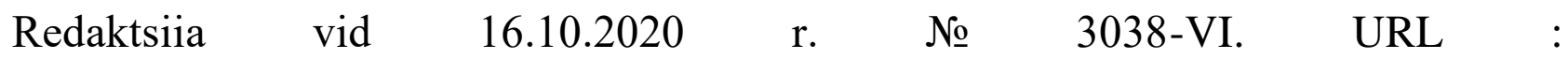
https://zakon.rada.gov.ua/laws/show/3038-17\#Text

5. Zemelnyi kodeks Ukrainy vid 25.10.2001 r. № 2768-III. URL : https://zakon.rada.gov.ua/laws/show/2768-14\#Text

6. DSTU 1.5:2015 «Pravyla rozroblennia, vykladannia ta oformlennia natsionalnykh normatyvnykh dokumentiv». Natsionalna standartyzatsiia. URL : https://udhtu.edu.ua/wp-content/uploads/2018/03/DSTY_1_5_2015.pdf

Дорош Й.М., Харитоненко Р.А., Бутенко С.В., Мельник Д.М.

ГАЛУЗЕВИЙ СТАНДАРТ ПРОЕКТУ ЗЕМЛЕУСТРОЮ ЩОДО ОРГАНІЗАЦЇ̈ ТЕРИТОРІЇ ДЕРЖАВНИХ НАУКОВИХ УСТАНОВ

Проаналізовано нормативно-правові акти, наукові публікаиії та проекти землеустрою щуодо організаџї території зокрема державних наукових установ та підприємств Начіональної академії аграрних наук України (далі - НААН). Встановлено, щчо в чинному законодавстві відсутній вид документащії із землеустрою, щуодо вирішення питань організації території землекористувань 
державних установ та підприємств НААН. Наголочено та обгрунтовано на необхідності розроблення галузевого стандарту, що враховуватиме специфіку використання земель землекористувань установ та підприємств НАAН, що мають у своєму складі земельні ділянки, дослідні поля, розсадники, ичінні землі для ведення наукових досліджень, що необхідно враховувати при розробленні документаиії із землеустрою. Запропоновано визначення терміну організація території. Розглянуто оформлення нормативних документів (галузевого стандарту) відповідно до ДСТУ 1.5:2015, щзо вказує на типові структурні елементи, які необхідні показати при розроблені стандарту. Запропоновано галузевий стандарт проекту землеустрою щзодо організації території землекористування державних установ та підприємств НААН враховуючі специфічні функціональні особливості використання сільськогосподарських земель державних установ та підприємств НАAН.

Ключові слова: стандартизація, галузевий стандарт, організація території, науково-дослідне землекористування, НААН

Дорош И.М., Харитоненко Р.А, Бутенко Е.В., Мельник Д.М.

ОТРАСЛЕВОЙ СТАНДАРТ ПРОЕКТА ЗЕМЛЕУСТРОЙСТВА ПО ОРГАНИЗАЦИИ ТЕРРИТОРИИ ГОСУДАРСТВЕННЫХ НАУЧНЫХ
УЧРЕЖДЕНИЙ

Проанализированы нормативно-правовые акты, научные публикации и проекты землеустройства по организации территории в частности государственных научных учреждений и предприятий Наџиональной академии аграрных наук Украины (далее - НААН). Установлено, что в действующем законодательстве отсутствует вид документации по землеустройству, по решению вопросов организации территории землепользования государственных учреждений и предприятий НААН. Отмечено и обоснованно необходимость разработки отраслевого стандарта, учитывать специфику использования земель землепользования учреждений и предприятий НААН, имеющих в своем составе земельные участки, опытные поля, питомники, 
цеенные земли для ведения научных исследований, что необходимо учитывать при разработке документации по землеустройству. Предложено определение срока организация территории. Рассмотрены оформления нормативных документов (отраслевого стандарта) в соответствии с ГОСТ 1.5: 2015, что указывает на типичные структурные элементы, которые необходимы показать при разработань стандарта. Предложено отраслевой стандарт проекта землеустройства по организащии территории землепользования государственных учреждений и предприятий НААН учитывая специфические функциональные особенности использования сельскохозяйственньх земель государственных учреждений и предприятий НААН.

Ключевые слова: стандартизация, отраслевой стандарт, организациия территории, научно-исследовательское землепользования, НААН. 